\title{
Pensonomonoor
}

2017, vol. 78, 136-145

http://dx.doi.org/10.12657/denbio.078.013

Katarzyna Gtębocka, Magdalena Pogorzelec*

\section{Genetic diversity of the Salix lapponum L. population intended as a source of material for reintroduction}

\author{
Received: 6 March 2017; Accepted: 2 July 2017
}

\begin{abstract}
Salix lapponum is a relict species that occurs in peat bogs. The most numerous population in Poland, which is located on Lake Bikcze, was selected as a source of plant material for genetic analysis to check if it could be used to translocate and establish new populations in the future. For this purpose, the genetic variability of five groups of plants, which were located 50 to $130 \mathrm{~m}$ away from one another, was assessed using the AFLP method. GenoType software did not indicate clonal individuals in the studied population. Although the groups were located at short distances from one another, the genetic differentiation between them, expressed as $\Phi_{\mathrm{PT}}$ and $\mathrm{G}_{\mathrm{ST}}$ coefficients, was very high and the clustering methods adopted showed the presence of genetic structure. The lack of correlation between geographic distance and pair-wise $\Phi_{\mathrm{PT}}$ indicated that at least in the past the gene flow was fluent, but nowadays seedling recruitment is barely visible. These results can be explained by the fact that from the beginning of the 21 st century the Lake Bikcze population has dramatically decreased in size. On the other hand, the expected heterozygosity in each group is quite high. If we want to use this population as a donor of reproductive material, action should be taken as quickly as possible.
\end{abstract}

Keywords: reintroduction, genetic diversity, Salix lapponum

Addresses: K. Głębocka, Institute of Plant Genetics, Breeding and Biotechnology, Faculty of Agrobioengineering, University of Life Sciences in Lublin, Poland, e-mail: katarzyna.glebocka@up.lublin.pl M. Pogorzelec, Department of Hydrobiology, Faculty of Biology, Animal Sciences and Bioeconomy, University of Life Sciences in Lublin, Poland, e-mail: magdalena.pogorzelec@up.lublin.pl

*corresponding author

\section{Introduction}

Salix lapponum L. (downy willow) is one of the two relict boreal species from the family Salicaceae that now occurs in eastern Poland (the other one is S. myrtilloides). This is an inconspicuous shrub, reaching a height of $1 \mathrm{~m}$ up to $2 \mathrm{~m}$. Downy willow is a perennial plant, a nanophanerophyte, characterized by dioecy. It is an entomophilous and melliferous species (Kruszelnicki et al., 2014; Pogorzelec et al., 2014a).

$S$. lapponum is commonly found in subarctic and boreal peatlands of Northern and Northeastern Europe as well as of western Siberia. Isolated populations are also encountered in some mountain ranges of Central and Southern Europe as well as in Scotland (Kruszelnicki et al., 2014). 
In lowland areas of Poland, S. lapponum occurs mainly on the eastern side of the Vistula River. Currently, its confirmed stands are located in the Łęczna-Włodawa Lakeland in the Polesie National Park, in the Biebrza National Park, and in the Knyszyńska Forest. Two populations in the Karkonosze Mountains grow on the subalpine floor as an endemic association of Salicetum lapponum W. Mat. 1965 (Kruszelnicki et al., 2014; Pogorzelec et al., 2014a).

This plant prefers specific habitat conditions that are found in eastern Poland only in peatland ecosystems (Pogorzelec et al., 2014b; Kołos et al., 2015; Serafin et al., 2015): sunny or partially shaded wet and moist places, $\mathrm{pH} 4-6$, oligotrophic or mesotrophic habitats, but abundantly rich in organic matter marshy soils in fens, less frequently in transitional bogs. It generally occurs individually or in small clusters (Pogorzelec, 2008; Serafin et al., 2015).

S. lapponum is legally protected in Poland, but the number of its stands and its population size have systematically decreased since the 1950's (Pogorzelec et al., 2014a). As a glacial relict, it has the status of critically endangered species (CR) according to the 'Polish Red Book of Plants'. This species should be subjected to immediate conservation in order to restore appropriate levels of distribution of the populations that still exist in Poland (Kruszelnicki et al., 2014; Mirek et al., 2006).

Multidirectional research on S. lapponum has been conducted in the Polesie Lubelskie region since 2000 and it includes issues related both to the functioning of its populations (among others, changes in population numbers, sex ratio, among- and within-population genetic diversity) and to particular individuals (selected key stages of the breeding cycle) (Pogorzelec et al., 2014c). Active conservation of this species, involving the establishment of new populations and the replenishment of the existing populations occurring in the Polesie National Park, should be an action that will be the ultimate outcome of the efforts to fully get to know this species. According to Guerrant (2007), the most important goal of reintroduction of endangered plant species is to establish resilient and self-sustaining populations that have sufficiently diverse gene pools to undergo adaptive evolutionary change. Attempts to reintroduce rare species often fail due to the fact that the implementation of such reintroduction programs is not based on reliable knowledge of their biology and ecology (Reading et al., 2002). Taking into account the above, an attempt was undertaken to determine whether the most numerous $S$. lapponum population in eastern Poland can become a source of plant material for ex situ breeding and in consequence be used to replenish and establish new populations of this species. For this purpose, a study was conducted on the genetic variability of a selected population whose stand is located on Lake Bikcze - N5 $1^{\circ} 22.724^{\prime}$ E023 $02.563^{\prime}$ (Łęczna-Włodawa Lakeland) in order to evaluate the adaptive potential of individuals comprising this population.

\section{Materials and Methods}

\section{Study object and sampling}

Salix lapponum plants making up the most numerous (about 300 individuals) population of this species in eastern Poland were selected as a source of plant material for genetic analysis. This is a group of plants that is characterized by a stable sex ratio $(1: 1)$. Each year, more than $70 \%$ of individuals flower and produce seeds capable of germination (Pogorzelec et al., 2014c). However, since 2000 this population has tended to quickly reduce its resources, simultaneously exhibiting low recruitment of seedlings or the complete absence of seedling recruitment (Pogorzelec et al., 2014a). The reasons for this are mainly attributed to the changes occurring in the habitat, primarily the unstable groundwater level and the accelerated process of ecological succession that is manifested in the study area by a rapid expansion of undesired species, both herbaceous and woody plants. In the peat bog on Lake Bikcze, during the spring period there are unfavorable conditions for the growth of small-size willow seedlings. A too high water level in the spring probably does not allow them to be anchored in the soil or causes their quick death. S. lapponum shrubs comprising the population on Lake Bikcze are dispersed within an area of about 1 ha, making up 5 distinct groups located 50 to $130 \mathrm{~m}$ away from one another. Individual specimens grow both in the open bog in the sunny zone and among grey willow (S. cinerea) shrubs encroaching the bog area.

The number of analyzed plants in each of the five groups, which were named A - E, was approximately 30 individuals and DNA from 151 specimens altogether was isolated from the Bikcze population. The plant material was sampled randomly, but at least at a $1 \mathrm{~m}$ distance between individuals within one group. Young leaves of $S$. lapponum shrubs were collected in spring 2011 and kept frozen until DNA isolation, which was performed according to Porebski et al. (1997) with some alterations. Then, DNA content was measured and all samples were diluted to a final concentration of $20 \mathrm{ng} / \mu \mathrm{l}$.

\section{AFLP (Amplified Fragment Length Polymorphism) analysis}

The procedure was carried out according to Vos et al. (1995) with modifications. EcoRI and MseI 
enzymes were used for genomic DNA digestion for $3 \mathrm{~h}$ at $37^{\circ} \mathrm{C}$ and then they were inactivated at $70^{\circ} \mathrm{C}$. Adapter ligation was performed during $12 \mathrm{~h}$ incubation at $20^{\circ} \mathrm{C}$. DNA modified in this way was a template for pre-amplification reactions. The primers were complementary to the adapter sequences and they additionally had one selective nucleotide at 3' end. The first step of PCR was $94^{\circ} \mathrm{C}$ initial denaturation that lasted $2 \mathrm{~min}$ and it was followed by 30 cycles of denaturation, annealing and primer extension at $94^{\circ} \mathrm{C}, 56^{\circ} \mathrm{C}$ and $72^{\circ} \mathrm{C}$, respectively. Each of these steps lasted $1 \mathrm{~min}$. The final extension was carried out at $72^{\circ} \mathrm{C}$ for $5 \mathrm{~min}$. The reaction solutions were then diluted at $1: 19$ and $2.5 \mu \mathrm{l}$ was added as a template for selective amplification reactions. The primers for these reactions had three selective nucleotides and five different combinations were used: E-ACA/M-CAA, E-AGC/M-CAA, E-ACA/M-CAT, E-AAC/M-CAT, and E-AAC/M-CTC. The thermal profile was as follows: initial denaturation lasted 2 min at $94^{\circ} \mathrm{C}$, then 41 cycles with the succeeding steps followed: $94^{\circ} \mathrm{C}$ for $30 \mathrm{~s}$, a touchdown annealing temperature decreased from $65^{\circ} \mathrm{C}$ to $56^{\circ} \mathrm{C}$ in 13 cycles and during the subsequent 28 cycles this step had a constant temperature of $56^{\circ} \mathrm{C}$ for $30 \mathrm{~s}$, the extension step lasted $1 \mathrm{~min}$ at $72^{\circ} \mathrm{C}$, while the final extension was performed at $72^{\circ} \mathrm{C}$ for $5 \mathrm{~min}$. The products were separated on $6 \%$ denaturing polyacrylamide gels and then silver stained.

\section{Data analysis}

Based on the polyacrylamide gels, a binary matrix was obtained, where 1 was attributed to the presence of a band and 0 to the absence of a band. It was applied as a source data for further studies.

GenoType software (Meirmans \& Van Tienderen, 2004), which compares the band profiles of all pairs of individuals, was used to investigate clonality level in the studied population. The specimens that are separate genets should differ from each other in three or more loci. In contrast to that, identical or very similar profiles (one or two band differences) can indicate ramets of the same genet. The results are shown in the form of a plot where individuals that have the same number of band differences are gathered in separate groups.

To check whether each pair of loci was in linkage disequilibrium (LD), Arlequin ver. 3.5 (Excoffier et al., 2005) was adopted. The significance of association was tested using the $\chi^{2}$ test $(\mathrm{p}=0.05)$ (Miyashita et al., 1999). The number of loci in disequilibrium was compared to all possible pairs in order to define the LD loci percentage in the whole population or each group from A to E separately.

Unbiased expected heterozygosity $\left(\mathrm{H}_{\mathrm{e}}\right)$, percentage of polymorphic products as well as private bands were estimated by GenAlex 6.502 (Peakall \& Smouse, 2012).

In order to assess if there is a genetic structure of the five groups making up the population from Lake Bikcze, different analyses were conducted. Principal Component Analysis (PCA) was carried out using Past3 (Hammer et al., 2001). 95\% concentration ellipses were designated for each group. Past 3 software was also used to construct UPGMA tree which was based on Jaccard's similarity matrix. The cophenetic correlation coefficient was estimated for dendrogram. The last method used to seek the genetic structure was a Bayesian approach implemented using STRUCTURE 2.3.4. software (Pritchard et al., 2000). The following parameters were defined for this analysis: 150000 burn-ins, 100000 iterations of Markov chain Monte Carlo (MCMC), admixture and correlated allele frequencies models. From 1 to 8 genetic clusters $(\mathrm{K})$ were tested and the number of replicates for each $\mathrm{K}$ value was set to 20 . In order to indicate the most possible number of genetic clusters, a procedure based on the second-order rate of change of the likelihood function $(\Delta \mathrm{K})$, described by Evanno et al. (2005), was included. The online program Structure Harvester (Earl \& von Holdt, 2012) was used to carry out this process. Finally, CLUMPP (Jakobsson \& Rosenberg, 2007) and DISTRUCT (Rosenberg, 2004) softwares were employed to present the results in graphical form.

The next part of the analysis was to check how much of the genetic variation was located between the groups of individuals and therefore two coefficients were computed. The first one was $\Phi_{\mathrm{PT}}$, which was estimated by AMOVA procedure in GenAlex, with 10000 permutations. The other one is $G_{\mathrm{ST}}$ and it was calculated according to the following formula: $\left(\mathrm{H}_{\mathrm{T}}-\mathrm{H}_{\mathrm{S}}\right) / \mathrm{H}_{\mathrm{T}}$, where $\mathrm{H}_{\mathrm{T}}$ is total genetic heterozygosity and $\mathrm{H}_{\mathrm{S}}$ is the mean value of heterozygosity for all populations. The Mantel test (Mantel, 1967) was applied to seek the relationship between pairwise $\Phi_{\mathrm{PT}}$ and geographical distance. The statistical significance was checked by performing 10000 permutations.

\section{Results}

The first step of the analysis was to verify clonality. The GenoType software did not indicate clonal individuals in the studied population (Fig. 1). The lowest number of band differences between specimens was five and this pair of individuals belonged to group C. Based on these results, it can be stated that each S. lapponum plant from Lake Bikcze that was taken for analysis was a separate genet.

At the whole population level, the contribution of LD loci was over four times higher than expected by chance $(5 \%)$ (Table 1$)$. When the groups were 


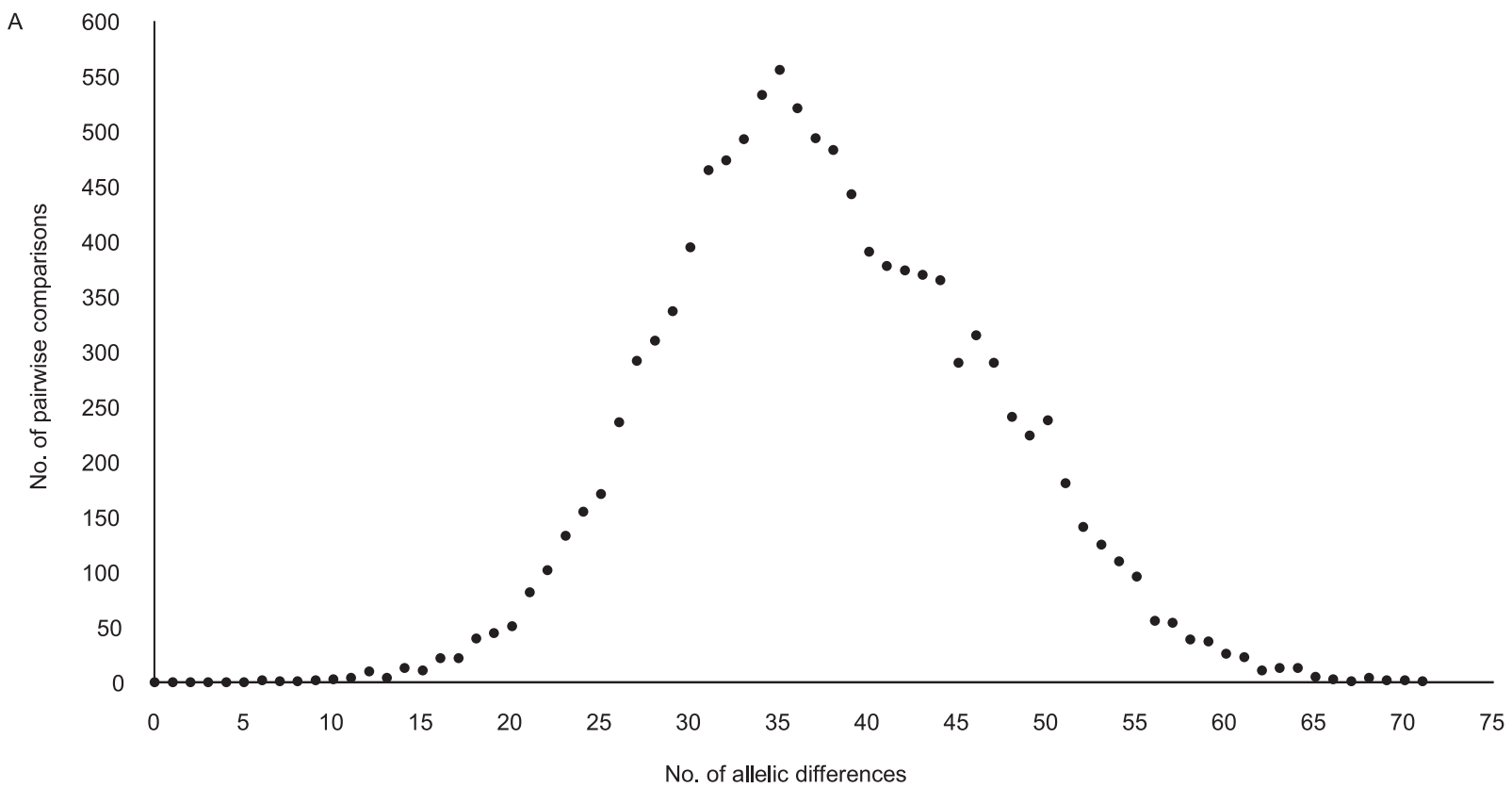

Fig. 1. A histogram of the number of allelic locus differences for each possible Salix lapponum individuals' pair based on GenoType software results from the AFLP matrix

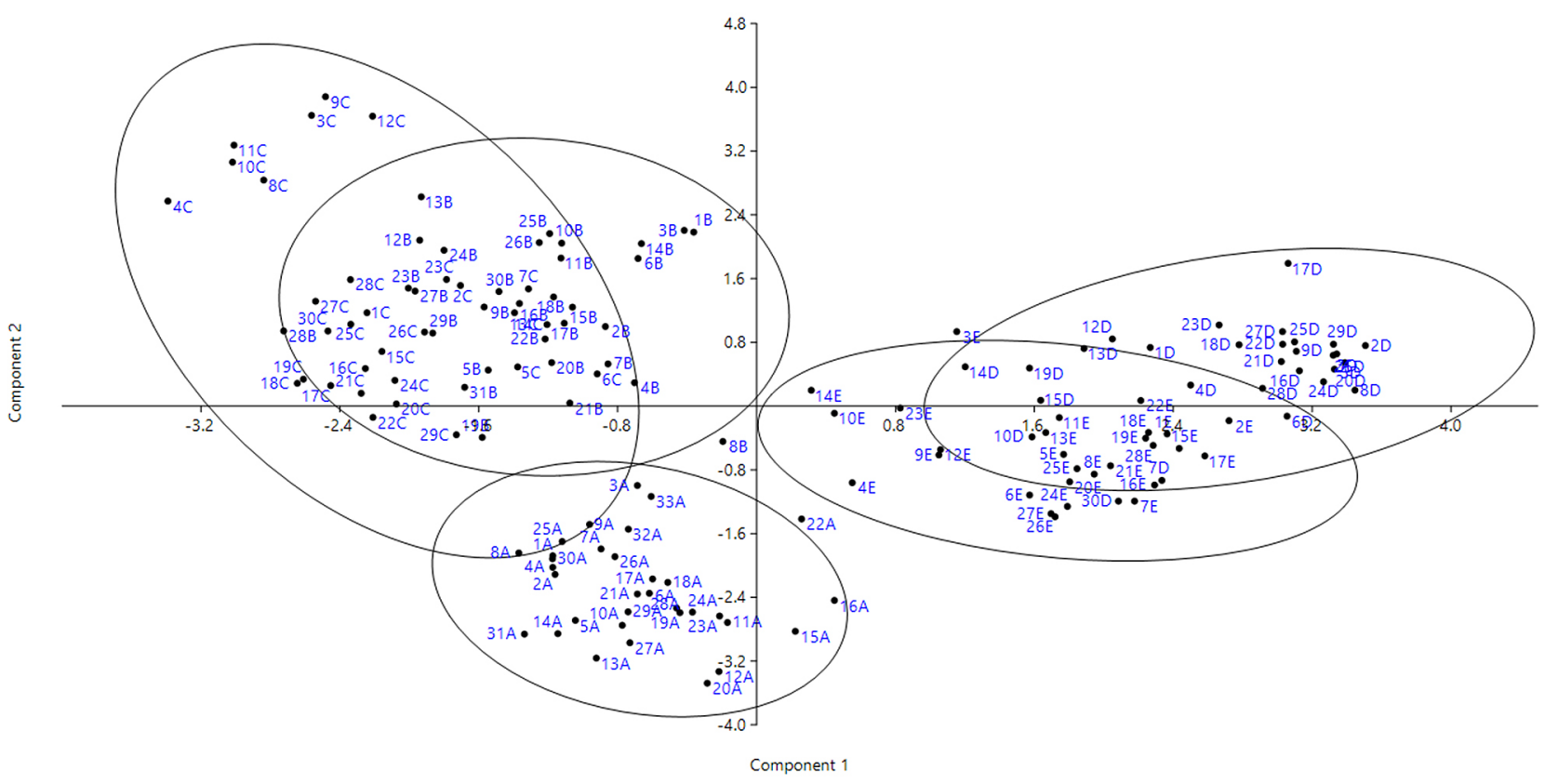

Fig. 2. The principal component analysis (PCA) plots based on AFLP data for S. lapponum. The ellipses indicate a region on the plot where $95 \%$ of group points are expected to appear

Table 1. Linkage disequilibrium at 0.05 level in each group separately and the whole population of S. lapponum based on the AFLP matrix

\begin{tabular}{lcccccc}
\hline \multicolumn{1}{c}{ Group of individuals } & A & B & C & D & E & The whole population \\
\hline No. of loci combinations & 11476 & 11325 & 11476 & 11476 & 11476 & 11476 \\
No. of LD loci combinations & 577 & 668 & 885 & 538 & 484 & 2348 \\
Percentage of LD loci & 5.03 & 5.90 & 7.71 & 4.89 & 4.22 & 20.46 \\
\hline
\end{tabular}




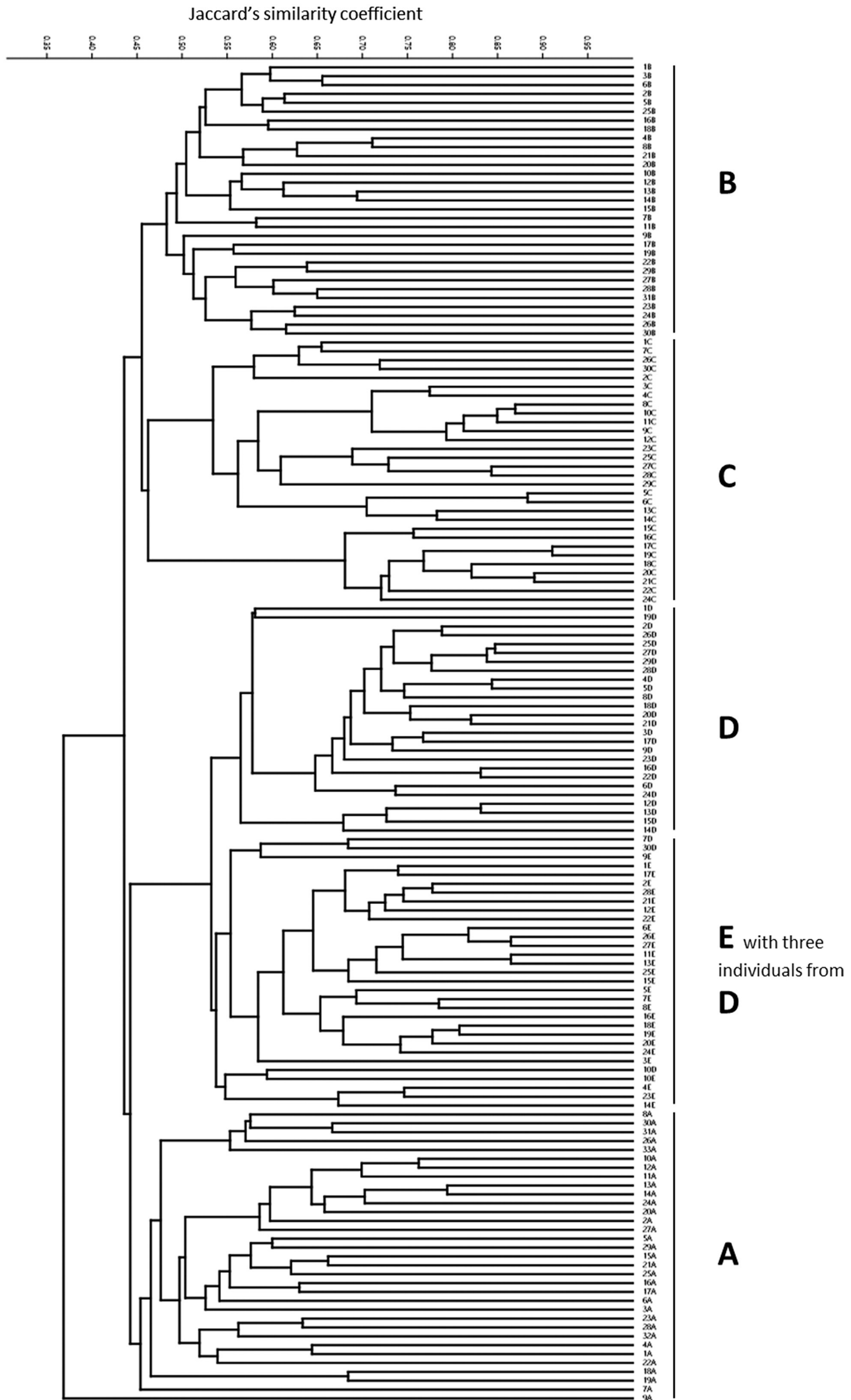

Fig. 3. Dendrogram depicting Jaccard's similarity based on the AFLP matrix of five Salix lapponum groups from the Lake Bikcze population 


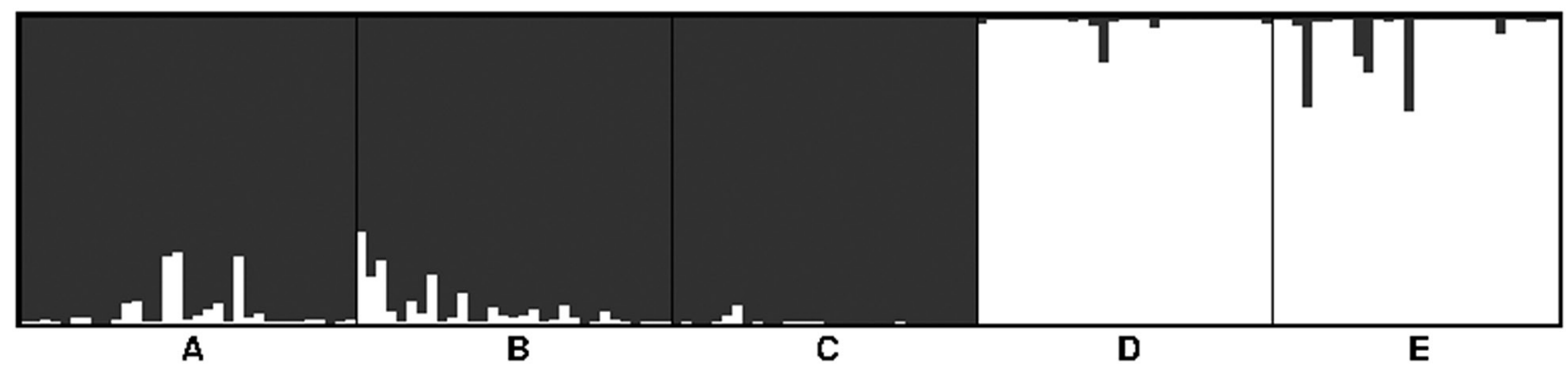

Fig. 4. The graphic representation of the Salix lapponum structure for AFLP method for 2 clusters assumed $(K=2)$. White and grey represent diverse genetic backgrounds and black vertical lines separate groups

Table 2. The within-group genetic diversity of S. lapponum from the Lake Bikcze population based on AFLP data

\begin{tabular}{ccccc}
\hline Groups & No. of bands & Percentage of polymorphic loci & No. of private bands & Unbiased expected heterozygosity $\left(\mathrm{H}_{\mathrm{e}}\right)$ \\
\hline A & 133 & 75.82 & 0 & 0.204 \\
B & 145 & 82.35 & 2 & 0.230 \\
C & 124 & 66.67 & 1 & 0.183 \\
D & 137 & 71.24 & 0 & 0.196 \\
E & 131 & 66.67 & 1 & 0.190 \\
Total & 153 & - & 4 & - \\
\hline Mean & - & 72.55 & - & 0.201 \\
\hline
\end{tabular}

analyzed separately, the frequency of linkage disequilibrium loci pairs was much lower, but in most cases it was still greater than $5 \%$.

The percentage of polymorphic loci was $72.55 \%$ and it exceeded $80 \%$ only for group B. These results were reflected in unbiased expected heterozygosity $\left(\mathrm{H}_{\mathrm{e}}\right)$, which was the highest also for group B. Altogether, four private bands were obtained.

All procedures that were designed to cluster individuals indicated the genetic structure of all analyzed groups. On the PCA plot (Fig. 2), group A was the most separated from the rest of the population, but groups B and C as well as D and E overlapped considerably. The first and second components explained, respectively, $10.98 \%$ and $6.14 \%$ of the variance. The same pattern was observed in the dendrogram (Fig. 3) which had clusters that suited all the five groups. The cophenetic correlation was equal to 0.7895 .

STRUCTURE analysis showed that the most probable number of genetic clusters was $2(\mathrm{~K}=2)$ (Fig. 4). The distribution of genetic background was similar to the PCA plot: groups A, B and C shared membership to one cluster, while groups $\mathrm{D}$ and $\mathrm{E}$ belonged to the other one, both with only a little admixture of the opposite background.

The differentiation among groups based on the AMOVA procedure revealed that $25 \%$ of the variation was distributed between groups $\left(\Phi_{\mathrm{PT}}=0.25\right)$. This result was significant after performing 10000 permutations. The $\mathrm{G}_{\mathrm{ST}}$ parameter was also very high $\left(\mathrm{G}_{\mathrm{ST}}=0.23\right)$.

The Mantel test showed no correlation between geographic distance and pairwise among-group differentiation $\left(\Phi_{\mathrm{PT}}\right)(\mathrm{r}=0.213, \mathrm{p}=0.228)$.

\section{Discussion}

According to Ren et al. (2014), it is more probable that reintroduction of a species will be successful if individuals used as the source of genetic material come from different populations. Alternatively, Godefroid (2011) states that multiple sources of plant material are not necessary if a single population has sufficient genetic diversity and plants should be reintroduced from material originating from a population whose numbers are not at risk of decreasing. Due to the risk of impoverishment of the gene pool associated with inbreeding or genetic drift, it is extremely important that the source population should be characterized by optimum gender structure, while individuals should be capable of generative reproduction. It is extremely problematic when in a given area there is only one population that can potentially be a source of plant material for reintroduction. We have to do with such a situation in the case of the relict species S. lapponum. A survey of its stands shows that in eastern Poland there is only one population of this species that can be considered to be functioning properly, despite that its numbers have been observed to decrease significantly since 2000 . The population located on Lake Bikcze was selected as the only one that offers a chance of obtaining sufficiently diverse plant material thanks to which it will be possible to establish an ex situ plant nursery necessary to carry out active conservation measures.

Despite that the Lake Bikcze population consists of territorially separate groups (which were designated with letters from A to E in this study), due to the small distances between them it was expected 
that the intensive gene flow would contribute to low among-group diversity and the lack of population structure. However, the results obtained based on the AFLP method proved to be totally different. The applied clustering methods (PCA, UPGMA dendrogram based on Jaccard's similarity and STRUCTURE analysis) showed the presence of genetic structure. Moreover, there was a clear division into two separate clusters: the first one included the overlapping groups A - C, while the second one comprised groups D and E. The analysis of molecular variance (AMOVA) revealed that most of the genetic diversity was located within the groups $(\mathrm{A}-\mathrm{E})$, but the $\Phi_{\mathrm{PT}}$ value was extremely high for groups located at such a close distance. It was similar in the case of the $\mathrm{G}_{\mathrm{ST}}$ coefficient. These values were especially surprising in the light of the results described in the paper by Pogorzelec et al. (2014c), where the genetic diversity obtained by ISSR markers between four populations located in the Łęczna-Włodawa Lakeland was twice smaller. The present $\Phi_{\mathrm{PT}}$ value may result from very high linkage disequilibrium of loci, which was especially high at the whole population level, and from applying the AFLP method whose results in many publications significantly differ from those obtained by ISSR (Abdelhamid et al., 2014; Badfar-Chaleshtori et al., 2012; Chen et al., 2010; Khadivi-Khub \& Soorni, 2014).

Despite that $S$. lapponum seeds are wind dispersed, they are usually deposited close to the parent plant due to the specific structure of the phytocenosis at the studied site (Pogorzelec et al., 2014b). Its pollen is carried by insects that could certainly cover the distances within the area occupied by the entire population, but due to the quite weak recruitment of young individuals, which seems to be a feature characteristic of the genus Salix (Douhovnikoff et al., 2005; Sochor et al., 2013; Stamati et al., 2007) we cannot notice the effects of gene flow at this level. However, the lack of correlation between genetic differentiation and geographic distance may indicate that at least in the past the gene flow was fluent. If the loss of alleles as a result of genetic drift is not compensated by the inflow of migrants from other groups of individuals, such a population is at the risk of losing its genetic diversity (Young et al., 1996). This is a very disturbing conclusion not only for the analyzed population but for the entire species, because it shows that under peatland conditions S. lapponum is not able to maintain even the minimum level of seedling recruitment and species continuity without human intervention. The S. lapponum stands in the eastern Poland are located only on peat bogs. Many of these ecosystems have been destroyed and fragmented since the 1950's (mainly by the Wieprz-Krzna Canal system, the Lublin Coal Basin, and agriculture) and now are isolated from each other by environmental barriers that limit gene flow by diaspores. Natural and anthropogenically induced changes in habitats influence their quality and hence proper functioning of sensitive relict species (Serafin et al., 2015).

Information on the demographic changes that have taken place in this population from the beginning of the 21st century can also be useful in the interpretation of these results. Still in 2000, several thousands of $S$. lapponum individuals were recorded on Lake Bikcze. The current resources of this population are estimated at about 300 individuals. Such a drastic decrease in population size over a very short time could have caused a bottleneck effect. The present population is only a small fraction of the one that existed over a dozen years ago and therefore it should be assumed that the alleles, also including rare or even unique ones, have been lost together with the lost individuals. From another point of view, the Bikcze population is still the most numerous in eastern Poland and the only one with $100 \%$ polymorphic loci (Pogorzelec et al., 2014c). It is not certain what factor caused such sudden extinction of so many individuals, but it can surely be said that the population has been genetically impoverished to a large extent. In spite of that, in each of the analyzed groups of S. lapponum individuals (A-E) the parameters determining within-population diversity (the proportion of polymorphic loci, heterozygosity) were high. Such comparison of the results shows that the fragmentation occurred relatively recently, which is also indicated by the conclusions drawn by Gareca et al. (2013) who analyzed divided populations of species of the genus Polylepis. Downy willow is a long-living species and the individuals that are now growing on Lake Bikcze were most probably present there over a dozen or even several dozen years ago; hence, we can assume that no significant transformation between the generations has taken place there over this time and that the high genetic diversity of the particular groups is a remnant after a numerous and dense population that existed there previously. Unfortunately, each successive generation produced by generative reproduction in a population whose habitat has been fragmented is usually characterized by a much lower level of heterozygosity (Aguilar et al., 2008; Gareca et al., 2013). Taking into account that it is the only population in Łęczna-Włodawa Lakeland with young individuals, this can be a reason for the smallest value of heterozygosity of the Bikcze population in Pogorzelec et al. (2014c). Due to that fact, the studied population should be used as quickly as possible as a donor of reproductive material in the form of both seeds and organ parts for in vitro regeneration. The longevity of $S$. lapponum individuals protects this species against the loss of its genetic diversity (Young et al., 1996; Gugerli et al., 1999; Stehlik et al., 2001; Nybom, 2004) and gives time to take measures aimed at its active conservation. Another 
factor that can delay the negative consequences of habitat fragmentation and population isolation is the capacity for vegetative reproduction which extends the periods between individual generations (Brzosko et al., 2009; Hilmo et al., 2012). However, the analysis performed using GenoType software revealed the absence of individuals with identical product profiles in the studied population. Based on the results obtained by Pogorzelec et al. (2014c) and Stamati et al. (2007), S. lapponum reproduces mainly sexually.

Despite that currently it is most numerous in eastern Poland, the S. lapponum population on Lake Bikcze has been drastically reduced over the last dozen or so years. From the genetic point of view, two parameters can be clearly seen: high diversity among the distinguished groups of individuals making up the population (expressed as the $\Phi_{\mathrm{PT}}$ and $\mathrm{G}_{\mathrm{ST}}$ coefficients) and high within-population differentiation. While the former one indicates that the population as a whole is not homogenous, the high value of heterozygosity is a positive signal since it gives a chance of preserving this feature among individuals that will be obtained with human participation and introduced at different locations. Given that, active conservation measures for Salix lapponum should be taken as quickly as possible.

\section{Acknowledgements}

The study was supported by the research grant N N 304385239 from Poland's Ministry of Science and Higher Education. The plant material of S. lapponum was collected in compliance with the permits issued by the Regional Director for Environmental Protection in Lublin (Permit No. RDOŚ-06WPN/66301-006/10/mpr and Permit No. WPN.6402.6.2011.MPR).

\section{References}

Abdelhamid SLê, Conedera M \& Küepfer P (2014) The assessment of genetic diversity of Castanea species by RAPD, AFLP, ISSR, and SSR markers. Turkish Journal of Botany 38: 835-850. doi:10.3906/bot-1303-30.

Aguilar R, Quesada M, Ashworth L, Herrerias-Diego Y \& Lobo J (2008) Genetic consequences of habitat fragmentation in plant populations: susceptible signals in plant traits and methodological approaches. Molecular Ecology 17: 5177-5188. doi:10.1111/j.1365-294X.2008.03971.x.

Badfar-Chaleshtori S, Shiran B, Kohgard M, Mommeni H, Hafizi A, Khodambashi M \& Sorkheh K (2012) Assessment of genetic diversity and structure of Imperial Crown (Fritillaria imperialis L.) populations in the Zagros region of Iran using AFLP, ISSR and RAPD markers and implications for its conservation. Biochemical Systematics and Ecology 42: 35-48. doi:10.1016/j. bse.2011.12.027.

Brzosko E, Wróblewska A, Ratkiewicz M, Till-Bottraud I, Nicole F \& Baranowska U (2009) Genetic diversity of Cypripedium calceolus at the edge and in the centre of its range in Europe. Annales Botanici Fennici 46: 201-214. doi:10.5735/085.046.0303.

Chen Y, Wang L, Ma Y, Xiao H, Tang L \& An Q (2010) Genetic diversity of Ligusticum chuanxiong Hort. based on inter simple sequence repeat (ISSR) and amplified fragment length polymorphism (AFLP) analyses. African Journal of Biotechnology 9: 8290-8295. doi:10.5897/AJB09.853.

Douhovnikoff V, McBride JR \& Dodd RS (2005) Salix exigua clonal growth and population dynamics in relation to disturbance regime variation. Ecology 86: 446-452. doi:10.1890/04-0257.

Earl DA \& von Holdt BM (2012) Structure Harvester: a website and program for visualizing STRUCTURE output and implementing the Evanno method. Conservation Genetic Resources 4: 359361. doi:10.1007/s12686-011-9548-7.

Evanno G, Regnaut S \& Goudet J (2005) Detecting the number of clusters of individuals using the software STRUCTURE: a simulation study. Molecular Ecology 14: 2611-2620. doi:10.1111/ j.1365-294X.2005.02553.x.

Excoffier L, Laval LG \& Schneider S (2005) Arlequin ver. 3.0: An integrated software package for population genetics data analysis. Evolutionary Bioinformatics Online 1: 47-50.

Gareca EE, Breyne P, Vandepitte K, Cahill JR, Fernandez M \& Honnay O (2013) Genetic diversity of Andean Polylepis (Rosaceae) woodlands and inferences regarding their fragmentation history. Botanical Journal of the Linnean Society 172: 544-554. doi:https://doi.org/10.1111/boj.12055.

Godefroid S, Piazza C, Rossi G, Buord S, Stevens AD, Aguraiuja R, Cowell C, Weekley CW, Vogg G, Iriondo JM, Johnson I, Dixon B, Gordon D, Magnanon S, Valentin B, Bjureke K, Koopman R, Virevaire M \& Vanderborght (2011) How successful are plant species reintroductions? Biological Conservation 144: 672-682. doi:10.1016/j.biocon.2010.10.003.

Guerrant Jr EO \& Kaye TN (2007) Reintroduction of rare and endangered plants: common factors, questions and approaches. Australian Journal of Botany 55: 362-370. doi:10.1071/BT06033.

Gugerli F, Eichenberger K \& Schneller JJ (1999) Promiscuity in populations of the cushion lant Saxifraga oppositifolia in the Swiss Alps as inferred from random amplified polymorphic DNA (RAPD). Molecular Ecology 8: 453-461. doi:10.1046/j.1365294X.1999.00586.x. 
Hammer $\varnothing$, Harper DAT \& Ryan PD (2001) PAST: paleontological statistics software package for education and data analysis. Palaeontologia Electronica 4.

Hilmo O, Lundemo S, Holien H, Stengrundet K \& Stenøien HK (2012) Genetic structure in a fragmented Northern Hemisphere rainforest: large effective sizes and high connectivity among populations of the epiphytic lichen Lobaria pulmonaria. Molecular Ecology 21: 3250-3265. doi:10.1111/ j.1365-294X.2012.05605.x.

Jakobsson M \& Rosenberg NA (2007) CLUMPP: a cluster matching and permutation program for dealing with label switching and multimodality in analysis of population structure. Bioinformatics 23: 1801-1806. doi: https://doi.org/10.1093/ bioinformatics/btm233.

Khadivi-Khub A \& Soorni A (2014) Comprehensive genetic discrimination of Leonurus cardiaca populations by AFLP, ISSR, RAPD and IRAP molecular markers. Molecular Biology Reports 41: 40074016. doi:10.1007/s11033-014-3269-4.

Kołos A, Wołkowycki D, Banaszuk P \& Kamocki A (2015) Protection of relict plant species at the limit of their geographical range: response of $\mathrm{Sa}-$ lix lapponum to competitor removal. Annales Botanici Fennici 52: 303-314. doi: http://dx.doi. org/10.5735/085.052.0505.

Mantel N (1967) The detection of disease clustering and a generalized regression approach. Cancer Research 27: 209-220.

Kruszelnicki J, Gostyńska-Jakuszewska M \& Rutkowski L (2014) Salix lapponum L. (wierzba lapońska): Polska czerwona księga roślin. Paprotniki i rośliny kwiatowe Wyd. III uaktualnione i rozszerzone (ed. by R Kaźmierczakowa, K Zarzycki \& Z Mirek) IB PAN \& IOP PAN.

Meirmans PG \& Van Tienderen PH (2004) GENOTYPE and GENODIVE: two programs for the analysis of genetic diversity of asexual organisms. Molecular Ecology Notes 4: 792-794. doi:10.1111/j.1471-8286.2004.00770.x.

Mirek Z, Zarzycki K, Wojewoda W \& Szeląg Z (2006) Czerwona lista roślin i grzybów Polski. W. Szafer Institute of Botany, Polish Academy of Sciences, Cracow.

Miyashita NT, Kawabe A \& Innan H (1999) DNA variation in the wild plant Arabidopsis thaliana revealed by amplified fragment length polymorphism analysis. Genetics 152: 1723-1731.

Nybom H (2004) Comparison of different nuclear DNA markers for estimating intraspecific genetic diversity in plants. Molecular Ecology 13: 11431155. doi:10.1111/j.1365-294X.2004.02141.x.

Peakall R \& Smouse PE (2012) GenAlEx 6.5: genetic analysis in Excel. Population genetic software for teaching and research - an update. Bioinformatics
28: 2537-2539. doi://doi.org/10.1093/bioinformatics/bts 460 .

Pogorzelec M (2008) Influence of chosen environmental abiotic factors on Salix lapponum L. populations functioning in Polesie Lubelskie Region. Polish Journal of Environmental Studies 17: 139144.

Pogorzelec M, Banach-Albinska B, Serafin A \& Szczurowska A (2014a) Population resources of an endangered species Salix lapponum L. in Polesie Lubelskie Region (eastern Poland). Acta Agrobotanica 67: 81-86. doi:10.5586/aa.2014.043.

Pogorzelec M, Bronowicka-Mielniczuk U, Banach B, Szczurowska A \& Serafin A (2014b) Relict boreal willows (Salix lapponum and Salix myrtilloides) as an element of phytocoenoses overgrowing the water Bodies in Eastern Poland. Applied Ecology and Environmental Researches 12: 441-456.

Pogorzelec M, Glebocka K, Hawrylak-Nowak B \& Parzymies M (2014c) Reproduction and diversity of the endangered Salix lapponum L. populations in Eastern Poland. Turkish Journal of Botany 38: 1239-1247. doi:10.3906/bot-1405-113.

Porebski S, Bailey LG \& Baum BR (1997) Modification of a CTAB DNA extraction protocol for plants containing high polysaccharide and polyphenol components. Plant Molecular Biology Reporter 15: 8-15. doi:10.1007/BF02772108.

Pritchard JK, Stephens M \& Donnelly P (2000) Inference of population structure using multilocus genotype data. Genetics 155: 945-959.

Reading RP, Clark TW \& Kellert SR (2002) Towards an endangered species reintroduction paradigm. Endangered Species Update 19: 142-146.

Ren H, Jian SG, Liu HX, Zhang QM \& Lu HF (2014) Advances in the reintroduction of rare and endangered wild plant species. Science China Life Sciences 57: 603-609. doi:10.1007/s11427-0144658-6.

Rosenberg NA (2004) DISTRUCT: a program for the graphical display of population structure. Molecular Ecology Notes 4: 137-138.

Serafin A, Pogorzelec M, Banach B, Szczurowska A \& Mielniczuk J (2015) Physico-chemical groundwater conditions at Salix lapponum stands in Eastern Poland. Dendrobiology 73: 65-74. doi:10.12657/ denbio.073.007.

Sochor M, Vašut RJ, Bártová E, Majeský L \& Mráček J (2013) Can gene flow among populations counteract the habitat loss of extremely fragile biotopes? An example from the population genetic structure in Salix daphnoides. Tree Genet and Genomes 9: 1193-1205. doi:10.1007/s11295-0130628-6.

Stamati K, Hollingsworth PM \& Russell J (2007) Patterns of clonal diversity in three species of sub-arctic willow (Salix lanata, Salix lapponum and 
Salix herbacea). Plant Systematics and Evolution 269: 75-88. doi:10.1007/s00606-007-0578-2.

Stehlik I, Schneller JJ \& Bachmann K (2001) Resistance or emigration: response of the high- alpine plant Eritrichium nanum (L.) Gaudin to the ice age within the Central Alps. Molecular Ecology 10: 357-370.

Vos P, Hogers R, Bleeker M, Reijans M, Van de Lee T, Hornes M \& Zabeau M (1995) AFLP: a new technique for DNA fingerprinting. Nucleic Acids Research 23: 4407-4414. doi: https://doi. org/10.1093/nar/23.21.4407.

Young A, Boyle T \& Brown T (1996) The population genetic consequences of habitat fragmentation for plants. Trends in Ecology \& Evolution 11: 413-418. 